Milk is an excellent item in the diet, but it is not always casily digested, and consequently it should be well diluted; it should be boiled to get rid of the Bacillus coli and other organisms. The following will servo an adult in the acute stage for twenty-four hours: About 2 pints of millk, 2 or 3 pints of barley water, whey, or plain water, 6 or $8 \mathrm{oz}$. of syrup of glucose, 4 or 5 drachms of table salt, and 1 drachm of the glycerophosphate of calcium.

If the syrup of glucose be too sweet or mawlish, a quarter of a pound of sugar of mills can be used. Later on the patient can have peptonized bread and milk or some infants' food, broths, raw eggs, jellies, cocoa or coffee, and a few bisouits. He can have cold water. when he likes; you can wait on the desire of the patient for solid food. Be always careful that the bowels are not loaded or distended.

In conclusion, I wish strongly to impress on you that pneumonia should always be looked upon as a serious disease; remember that no matter how mild the case may at first appear, you cannot always forecast how it may devclop, and every medical man, in dealing with this affection, should feel the responsibility of a liuman life in his liands. It has been said that young men kill their patients and old men allow them to die. I wish you to take a different course and direct them into a harbour of safety. Early recognition and prompt treatment will save many a valuable life.

\section{INVESTIGATIONS ON}

\section{SYPIILIS AS AFFECTING THE HEALTI OF THE COMMUNITY.}

A Sumiary of the Collective Examination of over 3,000 Cases by Clinical and Serological Methods.

Bi CARL H. BROWNING, M.D., D.P.H., DIRECTON OF THE LABORATORY OF CLINICAL PATHOLOGY OF THE

(From the Pathological Departinent of the University and Western Infirmary, Glasgow.)

Anr attempt to estimate the actual prevalence of a clisease such as syphilis in the community is a task attended with great difficulty. In the first place, the recognition of the disease when in an active state depends on the presence of sions which may be fugitive o: atypical in character. Secondly, when the evidence of clisease which has ceased to be active is being sought for one has to rely, perhap. wholly, on the history, which may be fallacious, through intent or through ignorance. With regard to the sirns of active disease, it must be borne in mind that practically no infective condition invariably presents cliaracteristic clinical appearances. The reason for this is obvious when one remembers that the manifestations of disease in any particular case depend on the virulence of the infective agent, the amount of virus gaining access to the tissues, and the particular deguee of resistance of the infected subject. Hence it happens that even such comparatively well-clefincl infections as diphtheria and typhoid fere 'seape detection in at least as many instances as are recognized. It is more or less true, of course, that these cases in which symptoms are so transient and mild as to escape detection are in slight need of treatment; but a second consideration, beyond that of the infected in diviclual, is the question of the welfare of those who come into association with him. The great tenckency of modern medicine is towards prevention, and in the case of .infections discases prevention must largely take the form of measures to diminish the infectivity of those affected. 'The essential precur'sor of such measures, howerer, is the accurate and compreheusire recogniticn of the disease. Now. when conditions with such comparatively characteristic symptomatology as diphtheria and typhoid ferer are radily missed, how much more frequently must syphilis escape detection, for here-we are dealing with a disease whose manifestations are of the most multifarious description.

A further consideration of the lighest importance is that the sibjects of syphilitic infection, unless treated by the rast cnergetic methods at our disposal, pass almost invariably through the carrier stage; - The part played by carriers in disseminating other infectious diseases has been amiply proved; but the number of individuals who after apparently complete recovery from typhoid ferer or diphtheria continue to harbour virulent organisms for long periods is relatively small in proportion to the sum total of those attacked by these diseases. In syphilis, on the other hand, it is well known that while, even without treatment, apparently complete restoration to health may follow the primary and secondary stages, the presence of the active virus is shown by the fact that the latent syphilitic is capable of infecting others, and the same loolds good when the latent state is induced by mercurial treatment. In the course of time infectivity diminishes, and it is commonly accepted that the subject of acquired syphilis when persistently treated with mercury ceases to be a source of danger after about tivo years. But the loss of infectivity may not occur for many years. Thus I have observed the case of a man who was treated with mercury for about six months after the appearance of the primary sore; during the subsoquent twenty-five years lie has remained apparently perfectly healtly, but he in. fected his wifc, whom he married thirteen years aftcr contracting the discase. The latent syphilitic in the early stage, although apparently hoalthy, is a source of gieat danger to others, and it must be clearly borne in mind that cases in this category are, in the absence of a history, practically unrecognizable by clinical methods.

Apart from the difficulties attached to the correct diagnosis of the nature. of existing lesions and to the recognition of infections in the latent stage, there is a further complication introduced by the fact that the characteristic primary and secondary stages may bo missed or suppressed altogether, so that the affected individual is actually not aware of his state. This seems to be specially true in the case of women, particularly when syphilitic. infection is associated with pregnancy; but a similar absence of early phenomena is met with in men also, and I have seen a case of tabes with rapidly progressing optic atrophy occur in a highly intelligent and well-informed man who had never, to his linowledge, presented any of the early signs of syphilis, although he volunteered the history of exposure to possible infection.

'To arrive, thereforc, at accurate conclusions regarding the prevalence of a disease with such varied features as syphilis, it. is neoessary to seek corroborative evilence from all possible sources. In the course of the past three years extensive clinical and serological observations on the part played by syphilis in the production of disease have been carried out in connexion with the Pathological Department of Glasgow University and Western Infirmary, where various workers have talken up special branches of investigation and have examined over 3,000 cases. At the present time, when interest. is being aroused regarding the importance of venereal diseases as affecting the health of the community, a useful object may be served by giving a brief summary of the principal results obtained, with a view to emphasizing their significance for the general health, and in order to point out very briefly their bearing on future measures which may aim at the amelioration of existing conditions.

\section{Methods of Investigatios.}

The information yielded by an investigation with the object liere described obviously depends for its accuracy and completeness on the correlation of different metliods of observation. This was clearly recognized, and it was apparent that, to obtain the most fruitful results, the clinical and the laboratory aspects of the conditions studied should either be examined by the same observers, or else by several workers, each of whom was conversant with all the problems - concerned in the cases. The complete investigation aimed at was to obtain in evcry instance :

(a) The clinical examination of the patient; (b) the examination of the members of the patient's family; (c) the history of the health of the patient and his family; (d) the result of the Wassermann test with the blood of the patient and of the members of his family.

It is abvious that the carying out of such a schemc in all its details is extremely tedious and frequently impossible. Dr. H. F. Watson has, howerer, investigated a large series of cases as far as possible on these lines, and has thereby done much to verify the specificity of the 
laboratory test-the Wassermann reaction-as indicating syphilis and nothing but syphilis. The consequence is that the validity of positive conclusions drawn from the Wassermann test cannot well be controverted, provided, of course, that the test is carried out under thoronghly reliable conditions. With regard to the significance of the Wassermann reaction, ${ }^{*}$ it was necessary to establish by personal experience the proof of its specificity for syphilis. It is, of course, well known that a positive reaction is obtained with the blood serum in

95 per cent. of cases of syphilis in the secondary stage.

75 per cent. of cases of syphilis in the tertiary stage.

50 per cent. of cases of syphilis in the latent stage.

95 per cent. of cases of congenital syphilis with lesions.

In order to be able to place reliance on the Wassermann reaction for purposes of diagnosis it was necessary to demonstrate that a positive result did not occur in conditions other than syphilis. The specificity of a positive reaction as a sign of syphilis has never been seriously doubted, so far as diseases common to this country are concerned. But the proof that a positive reaction really indicates syphilitic infection and does not occur under other circumstances is a matter of the highest importance, and I shall therefore adduce the evidence on this point which has been obtained here. In the first place, a number of workers in the laboratory have at different times given their serums for the purpose of controlling the tests, and in no instance has a positive result been obtained with such control serums. Secondly, Watson (un. published observations) examined a large series of cases, almost exclusively children, in which there was nothing suspicious either in the physical state or in the history of the individual and his family. $t$ The results were as follows (excluding 20 cases in which the Wassermann reaction was merely doubtful, with no other suspicious circumstance):

Result of Wassermann Reaction in 36t Selected Cases attending the Dispensary of the Royal Hospital for Sick Children and the Central Dispensary, Glasgorc.

Number of negative cases $\quad$... $\quad$... $\quad \ldots 351$

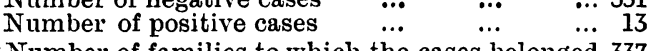

Number of families to which the cases belonged 337

Families yielding only negative reactions $\ldots 330$

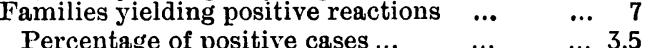

Percentage of positive cases $\ldots$
Percentage of families with positively $\ldots-3.5$

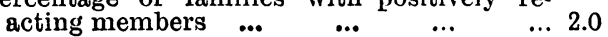

In a third of the above-mentioned cases the history was taken before the Wassermann test was applied. It is also interesting to note that of the positive cases 6 came from one family whose parents were also positive. The examination, in addition, of 69 country children belonging to 39 families did not yield a single positive reaction. On the other hand, the examination of 97 children belonging to 83 families, who either presented clinical evidence of syphilis, or in whose family or personal history there was evidence of the disease, gave the following results (excluding 14 other cases in which the Wassermann reaction was doubtful):

Result of Wassermann Reaction in 97 Children (belonging to S3 Families) presenting either Clinical Evidence or a Family History of Syphilis.

Number of positive cases $\quad$... $\quad \ldots \quad$... 70

$\begin{array}{lllll}\text { Number of negative cases } & \ldots & \ldots & \ldots & 70 \\ \text { Number of families yielding positive reactions. } & 66\end{array}$

Number of families yielding positive reactions..
Number of families yielding negative reactions 17

Accordingly 72 per cent. of the cases and 80 per cent. of the families react positively. This shows clearly how essential it is to apply the Wassermann test to as many members of a
family as possible, in order to make sure of detecting syphilitic infection.

It is evident from these results that the occurrence of a positive Wassermann reaction is not an isolated phenomenon, but stands in the closest relationship to other conditions which have been accepted by the majority

* This test was throughout performed by the method of Browning, Cruickshank, and Mackenzie (Browning and Mackenzie, Recent Alvances in the Diagnosis and Treatment of Syphitis, London, 1911). All cases were excluded from this group in which there was evidence present or history in the past of lesions of a recognized syphilitic character in the patient, his parents, or ather members of the in which other children of the family had been born prematurely or had died from suspicious conditions in infancy. of clinicians as presumptive evidence of syphil's As a consequence the important conclusion follows that a positive Wassermann reaction, even in the absence of other evidence, may be accepted as a valid proof of the presence of syphilis. This converse proposition laving been established, the Wassermann reaction now provides an invaluable method for detecting syphilitic infection. By this means positively reacting individuals, although they present no typical lesions, can be placed in the category of latent syphilitics. As has becn already seen 50 per cent. of cases, not otherwise recognizable, can bc detected thus. The Wassermann reaction accordingly affords an extremely useful weapon for the attack of clinical problems; its value is enhanced further by the fact that it is objective, as contrasted with personal examination. Thus the elucidation of a syphilitic history depends not merely on the skill and knowledge of -the examiner, but also on his personal qualities, and if he meets with a conscionsly untruthful subject the results of his examination are, of course, entirely vitiated. It is an old teaching, which $I$ in my generation received from Sir Hector Cameron, that it is useless to ask a man if he has had syphilis, for his denial will serve merely to shake confidence in one's own judgement, but will not alter the fact. In this connexion I may quote the unpublished results of Drs. Hislop Manson and Edgar Smith in a series of upwards of half a dozen men suffering from iritis. These patients all were unable to give the clinicians any clue as to the cause of their eye condition, but when the Wassermann reaction had been found positive in each case and they were informed that they must have been infected with syphilis, every man furnished corroborative 'details.

Another point which has been raised is whether a positive Wassermann reaction indicates that syphilitic infection is actually present at the time of examination, or whether the reaction may not indicate a change due to syphilis in the past. Doubt was thrown on the view that a positive reaction signifies existing infection by the almost universal positive results in cases of general paralysis; thus Gilmour ${ }^{1}$ in his series of cases obtained positive reactions with the blood serum in 96 per cent. Those authorities who held that general paralysis was a sequel-a "parasyphilitic condition" not due to the presence of the virus of syphilis, concluded therefore that a positive Wassermann reaction might persist or develop anew after the infection had died out. The failure to influence general paralysis by antisyphilitic treatment was also adduced as cvidence against the syphilitic nature of the disease. Witi regard to the latter point, the argument from resistance to treatment cannot be taken as valid; thus practically no one doubts that interstitial keratitis is a syphilitic manifestation, yet general experience has proved that many cases of interstitial keratitis do not respond to antisyphilitic remedies, eren when most energetically applied. In some unpublished casas of this kind treated with neo. salvarsan by Di. Hislop Manson, not merely did the disease fail to respond to treatment, but the second eve became similarly affected in the course of a series of intravenous injections of the drug.

Writing upon general paralysis and locomotor ataxia in 1909, Browning and Mackenzie ${ }^{3}$ stated that the evidence "strongly suggests the possibility that the syphilitic virus is an active agent in the production of parasyphilitic disease," and that "further search for the contaginm virum of syphilis in the body during the stage of general paralysis is necessary." The best confirmation of the syphilitic nature of these conditions is the finding of spirochaetes in the central nerrous system by Noguchi, Levaditi, and others.

\section{The Erfects of Syphilis on the 'Heatth of tile} Community.

We may now proceed to consider those discases in tho causation of which syphilis has been proved to play an important part, and the social conditions with which syphilis is closely associated.

$¥$ It is noteworthy that among 387 clinically unsuspicious cases 20 reacted doubtfully -5 per cent.; whereas of 111 cases to whicl suspicion attached 14 gave doubtful reactions-12.5 per cent. Tinu those those which presented no evidence of syphilis. 
The-1?revalence of Congenital S'yphilis.

Watson (unpublished observations) investigated 331 niselected cases attending the Dispensary of the Royal Hospital for Sick Children and the Central Dispensary, Glasgow, for the treatment of conditions which were not frankly syphilitic. The results were as follows:

\begin{tabular}{|c|c|c|c|c|c|c|}
\hline \multirow{2}{*}{\multicolumn{3}{|c|}{ No. of Cases. }} & & \multicolumn{3}{|c|}{ No. of Cases with Evidence of Syphilis. } \\
\hline & & & & \multirow{2}{*}{ Clinical. } & \multicolumn{2}{|c|}{ Positive Wassermann Reaction. } \\
\hline 236 & $\cdots$ & $\ldots$ & ... & & & 0 \\
\hline $35^{*}$ & $\cdots$ & $\cdots$ & $\cdots$ & 35 & & 35 \\
\hline 35 & $\cdots$ & $\cdots$ & ... & 14 & & (doubtful 35) \\
\hline 25 & $\ldots$ & $\cdots$ & $\ldots$ & 25 & $\cdot$ & 0 \\
\hline \multicolumn{3}{|c|}{ Total (331) } & $\ldots$ & 74 & & $\begin{array}{l}\text { Positive } 35 \\
\text { Doulbtful } 35\end{array}$ \\
\hline
\end{tabular}

$* 9$ of these suffered from perios titis or joint $s$ wellings.

Thus, among 331 cases representative of the general conditions which lead to the appearance of children at the outdoor department of a hospital, 10 per cent. are syphilitic, both on clinical evidence and as the result of the Wassermann test; 22 per cent. have a syphilitic association on clinical grounds, with confirmatory evidence from a doubtful result of the Wassermann test in 4 per cont. This gives practically conclusive evidence of syphilis in 14 per cent.

\section{Mental Deficiency and Epilepsy.}

Dr. Kate Fraser and Dr. Watson ${ }^{3}$ have examined 204 cases of mental deficiency and epilepsy in young subjects. The series of 99 cases examined by Dr.. Firaser mainly belonged to the class fit to attend special sc: ools; while the cases-105 in number-examined by 3r. ilatson were either under school age (13 being less tian 5 years old) or else were not fit to attend a school by reason of their mental defect. The results of the two independent observations were practically identical and may therefore be grouped together.

\begin{tabular}{|c|c|c|c|}
\hline , & $\begin{array}{l}\text { No. of } \\
\text { Cases. }\end{array}$ & \multicolumn{2}{|c|}{$\begin{array}{l}\text { No. of Cases with Positive } \\
\text { Wassermann Reaction. }\end{array}$} \\
\hline Cases with mental defect only ... & 94 & 48 & $\underset{51}{\operatorname{Per} \text { Cent. }}$ \\
\hline Cases with mental defect and & 33 & 15 & 45 \\
\hline $\begin{array}{l}\text { Cases with mental and physical } \\
\text { defect }\end{array}$ & 67 & 28 & 41 \\
\hline Cases with epilepsy only ... & 10 & 4 & 40 \\
\hline Total ... & 207 & 95 & 46 \\
\hline
\end{tabular}

The examination of other members of families of cases gave confirmatory evidence through the occurrence of positive reactions in 21 instances. In addition, the presence of syphilis in the families of 21 cases which themselves gave a negative or doubtful reaction was proved by the occurrence of positive reactions in other members, while 5 of the 6 negatively reacting cases of epilepsy had positively reacting relatives. Syphilitic infection was thus shown to be associated with 59 per cent. of the cases in all.

These results in epilepsy form a striking confirmation of Dean's ${ }^{4}$ observation that the syphilitic character of such cases is best determined by examining the patients at an early age, since the percentage of positive results rapidly diminishes after the sixteentli year.. Thus, Gilmour (unpublished observations), who examined 61 cases of epilepsy in adults at Gartloch District Asylum, obtained only 13 per cent. of positive reactions.

It is noteworthy that only 22 of the cases examined by Fraser and Watson showed stigmata of congenital syphilis-10 per cent.-a result which is in agreement with the generally recognized fact that those individuals who develop general paralysis as a result of acquired syphilis us ially do not" suffer "from any of the serere visceral or cutaneous lesions of the disease. Hence it would appear that there is an inverse ratio between syphilitic nerve damage and the ordinary somatic manifestations of syphilis, whether congenital or acquired. The general results are that syphilis is responsible for more than half of the cases of mental deficiency, with or without epilepsy, of whatever grade of sererity, and that the type of epilepsy which manifests itself at early ages is mainly of syphilitic origin.

\section{Heart Disease in Childien.}

Watson (unpublished) examined 25 cases of this kind; 7 reacted negatively, 1 donbtfully, and 17 positively in tho Wassermann test. The positive cases ranged in age from 1 month to 3 years. The mothers of 14 of these positive children and of the 1 doubtful case all gave a positive reaction; in every instance a positive reaction was obtained with some member of the families of the positive cases. Of the 7 negatives, aged 3 to 8 years, the mothers were examined in 5 instances, all with negative result; in every one of these cases the mother suffered from acute rheumatism during pregnancy. Thus, it appears that "congenital" cardiac disease has two main causessyphilis and rheumatism. A striking feature of the syphilitic type is the mortality; of the 18 syphilitic cases, 9 died when less than 6 months old.

\section{Deafness in Children.}

In conjunction with Dr. Kerr Love, Browning and Cruickshank ${ }^{5}$ have examined the blood of 82 deaf children, with the following results :

\begin{tabular}{|c|c|c|c|c|}
\hline Condition. & $\begin{array}{l}\text { No. of } \\
\text { Cases. }\end{array}$ & $\begin{array}{l}\text { No. of } \\
\text { Families } \\
\text { to which } \\
\text { the Cases } \\
\text { belong. }\end{array}$ & $\begin{array}{c}\text { No. of Cases } \\
\text { yielding } \\
\text { a Positive } \\
\text { Wasser- } \\
\text { mann } \\
\text { Reaction. }\end{array}$ & $\begin{array}{l}\text { No. of } \\
\text { Families } \\
\text { containing } \\
\text { Positively } \\
\text { Reactings } \\
\text { Members. }\end{array}$ \\
\hline $\begin{array}{l}\text { Congenital deafness } \\
\text { (not hereditary) }\end{array}$ & 46 & 41 & 6 & 6 \\
\hline Accuired deafness $\ldots$ & 36 & 33 & 7 & 8 \\
\hline $\begin{array}{l}\text { (Acquired deafness } \\
\text { combined with in- } \\
\text { terstitial keratitis }\end{array}$ & 4 & 4 & 4 & 4) \\
\hline
\end{tabular}

It is to be noted in this connexion that the investigation of other members of the families of these cases was by no means exhaustive. As Dr. Kerr Love has stated, con. genital deafness appears to be due to an expiring syphilis; thus in a family of five children, four of whom were born deaf, the blood was tested in every instance, and also in the case of the parents, but only one-a deaf childreacted positively. It is probable, therefore, that syphilis plays a much greater part in the production of this condition than can be detected by the Wassermann test applied at a date long after the disease has ceased to be active. An interesting result illustrating the association of syplinilis with acquired and congenital deafness was obtained in two families both of which contained positively reacting members, and in each of which cases of acquired and of congenital deafness occurred side by side; there was no case of interstitial keratitis in these families.

\section{Ozacna.}

J. F. Smith examined 52 cases (unpublished), which showed no definite clinical signs of syphilis, such as necrosis of the nasal bones, and in which no syphilitic history was obtained. Of the series 16 gave a positive Wassermann reaction (30 per cent.).

\section{Aortic Disease and Intrathoracic Tumour suspected of} being Aneurysm.

During the past two years 46 cases from the wards of the Western Infirmary were examined, with a positive Wassermann reaction in 64 per cent.

\section{N'ervous Diseases.}

The cases here recorded are in a sense selected, being the last 122 specimens of this nattre submitted from the 
wards of the Western Infirmary. The results are as follows:

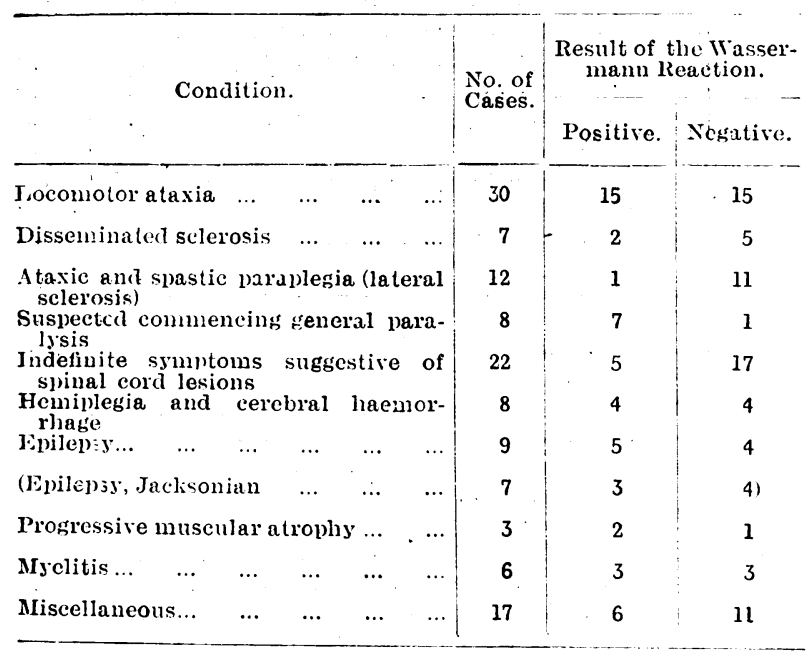

The information afforded by these results would have been much more complete had the cerebro-spinal fluids also been available for examination; as it is, the results of the Wassermann test confirm strikingly the generally accepted view as to the etiology of these conditions. Thus the large number of positives among tlic cases of locomotor ataxia and suspected general paralysis contrast with the preponderance of negative results in cases of disseminated sclerosis and affections of the lateral columns. The sum total of the results, however-41 per cent. of positivesindicates how frequent syphilis is among the cases of nervous disease in a general hospital.

\section{Iiye Diseases.}

The following figures, taken from Drs. Hislop Manson and Edgar Smith's unpublished observations, demonstrate the close relationship between syphilis and certain classes of eyo disease :

\begin{tabular}{|c|c|c|c|c|c|c|c|c|}
\hline \multirow{2}{*}{\multicolumn{3}{|c|}{ Condition. }} & \multirow{2}{*}{\multicolumn{2}{|c|}{. }} & & \multirow{2}{*}{$\begin{array}{l}\text { No. of } \\
\text { Cases. }\end{array}$} & \multicolumn{2}{|c|}{$\begin{array}{l}\text { Result of the Wasstr } \\
\text { mann Reaction. }\end{array}$} \\
\hline & & & & & & & Positive. & Negative. \\
\hline \multicolumn{3}{|c|}{ Interstitial keratitis } & $\cdots$ & $\ldots$ & $\ldots$ & 37 & 35 & 2 \\
\hline Iritis $\quad \ldots$ & $\ldots$ & ... & $\ldots$ & $\ldots$ & $\ldots$ & 22 & 12 & 10 \\
\hline Choroilitis & $\ldots$ & $\ldots$ & $\cdots$ & $\ldots$ & $\ldots$ & 20 & 5 & 15 \\
\hline Primary opt & at & phy & $\ldots$ & $\ldots$ & $\ldots$ & 5 & 5 & 0 \\
\hline
\end{tabular}

The striking result is the practically universal syphilitic nature of interstitial leratitis $(95$ per cent. of positive reactions), and probably of primary optic atroply, also the frequency of syphilis in cas ss of iritis (54 per cent. of positive reactions). Positive results were obtained in a number of cases of interstitial keratitis in which the disease had ceased to be active many years before the blood was tested.

\section{Paroxysmal Haemoglobinuric.}

Browning and Watson, ${ }^{6}$ as the result of an examination of 6 patients, and of other members of their families, in addition to an investigation of the cases recorded in the literature, have concluded that " the occurrence of a positive Wassermann reaction with the serum of the majority of cases of paroxysmal haemoglobinuria, along with the collateral evidence afforded by the presence of a positive Wassermann reaction with the serums of other members of the families, even where the patient reacts negatively, the history pointing to syphilis in the parents of haemoglobinuric children, and the stigmata of congenital syphilis in brothers and sisters, although absent in the patients themselves, constitute. a very strong basis for the opinion that syphilitic infection is practically invariably. present in cases of paroxysinal haemoglobinuria e frigore.

\section{Metritis and Uterine Haemorrhage, apart from} T'umour.

Out of 37 cases of this type investigated by Drs. A. L. and J. H. McIlroy along with H. F. Watson, ${ }^{7} 20$ reacted positirely, and 2 other's had positively reacting childrenthat is, syphilis was present in 59 per cent. Among 39 other gynaecological casses of indefinite origin studied by these observers, 18 reacted positively- 46 per cent. The cases wcre in attendance at the out-patient department of Glasgow Royal Infirmary, and were all of considerable severity. These results suggest that syphilis is very markedly associated with the more severe degrees of indefinite gynaecological ailments in women of this class.

\section{Social Conditions Associated with Syfhilis.} l'rostitutes.

Watson (unpublished observation) examined the blosd serum of 104 girls, aged 14 to 18 , half of whon resided in the poorest quarters, while the other half lived in the best residential districts. In crery iustance the Wassermaun reaction was positive. The importance of such a source of infection can hardly be overestimated, since it is obvious that, apart possibly from a certain proportion of congenital cases, infection nust have taken place recently, and therefore all must have been in a highly infective state.

\section{Tramss.}

Eighteen families, comprising 85 children, 14 mothers, and 10 fathers, wore cxamined by Watson (unpublished). In every instance a marked positive Wassermann reaction was obtained, and in the great majority of the families confirmatory evidence of syphilitic infection was elicited, so that the conclusion is justifiable that the Wassermann test was of direct value in detecting the presence of syphilis in the remainder (sce also Watson ${ }^{8}$ ). It is note worthy that with these people large families are the rule.

C'CNClesions.

I should hesitate to make the assertion, based on the Wasscrmann reaction in great part, that this long catalogue of conditions is closely associated with syphilis were it not that the wealth of control observations quoted at the commencement of this paper show in the most con. vincing fashion that the results of the Wassermann re. action r'm parallel with the indications afforded by clinical observations wherever such are available, and that a positive reaction is practically conclusive proof of existing syphilitic infection. In fact, the frequent occurrence of a negative Wassermamn reaction in latent syphilis and in locomotor ataxia shows that if the test errs in anything it is in the failure to retect a proportion of cases of syphilis. There is no evidence that a positive result is got in non -syphilitics cren in 1 per cent. of cases.

It is to be observed that no attempt has been made to gauge the prevalence of syphilis in the general population, but it is impossible to aroid the conclusion that syphilis is rery largely associated with the "hospitalized " portion of the community. and also with certain social classes which are peculiarly liable to spread the disease. Some hold that syphilis is diminishing in prevalence, and it is prcbable that the manifestations of the disease are now Jess obvious than in previous times, but no one is likely to view with cquanimity the widespread incidence revealed by investigations such as those described here. The great prevalence of syphilis among the invalid population, not to mention the wastage from abortions and infant deaths* due to congenital syphilis, shows elcarly the grave influence of thiis infection in deteriorating the worth of human material. In treatment we have a most potent remedy ready to hand; syphilis is highly amenable to treatment, but hitherto the disease has neither been adequatcly recognized nor sufficiently treated. Confining attention to the medical aspect, and neglecting such important social questions as the need for the adequate remuneration of many forms of female labour so as to make them truly self-supporting, there are two much needed reforms. In the first place, the widesi possible routine application

"The statistics of $\mathrm{Dr}$ A. K. ('halmers 'Glasgow), communicated to the Eightecnth Section of the International Congress of Medicine, the maternity history of in this connexion. Thus, his inguiry into children showed that 32 per cent. of their live-born children were dead mior to the occurrence of the stillbirth which gave rise to the inquiry. 
should be made of methods of diagnosis whererer they can be carried out from official somces on individuals not rathered together for this suecific purpose alone: for this purpose use could be made of the existing medical organizations : for the examination of children attending school, persons offering themselves for life insurance, patients under treatment at the out-patient department as well as in the wards of the hospitals; and also cases scen under the Insurance Act and so on. Cnder all circtunstances the examination should be made irrespectire of the fact that there are at the time no obvious signs of the discase. As a means of cliagnosis the Wassermann reaction. or some test fulfilling similar conditions. should occuly a prominent place on acconnt of its reliability as well as its capacity to detect the infection at latent periods. and also from the fact that it is not likely to cause such offence as a determined effort to obtain a history may give rise to." For statistical purposes the Wassermann reaction will vicle a truer conception of the actual prevalence of syphilis than can be arrived at from clinical records alone. Clinical statistics in gcoreral, but especially those compilca from experience in general private practice, must yiel too low an estimate of the incidence of syplitis, since adequate clinical iustruction in this disease is seldom given to students, so that medical men are not in a position to recognize unusual lesions or those slight manifestations which may constitute a vary large proportion of all the casies.!

'The second reform lias regard to methods of treatment. All cases of syphilis should be thorouglily treated. The necessity for thorough treatment must be cmiphasizer. 'The comparative inatequacy of the common form of mercurial therapy by pills is well seen from the results of MeIntosh and Fildes, ${ }^{9}$ who found that after two years of such treatment 30 per cent. of cases still reacted positively in the Wassermann test; while on clinical grounds, Jonathan Hutchinson, junr., ${ }^{10}$ admitted that 20 pei cent. of cases failed to be cured by this method. W'nest Lane, "convinced of the insufticiency of two vear of mercurial treatment, has recommended that it should be continued for five or seven years! The therapentic results can be greatly improved by the employment of salvarsan in addition to mercury. In the light of further cxperience, we alluere to our original statement that a siugle close of salvar'san is at least as efficient as a prolonged course of mercury, and produces its effect with greater rapidity. ${ }^{2}$ At present, however, very littlo use is made of the means at.disposal for treating cuses of syphilis.

Whereas the function of hospitals should be not merely to house cases of sickuess but also to treat them. there is nowadays the tendency for such iustitutions to do neither the one or the other with syphilitic patients. Cases of acquired syphilis are, at most, treated in the ontloor department with pills, powders, or mercurial solutionsa form of therapy which only very slowly extinguishes in fectirity, and, as usually carried ont, probably fails to effect cure in more than a small proportion of cases. Now there cain be no doubt that for the safety of the general community the infectivity of cases of recently acquired syphilis shonld be abolished as rapidly as possible. This can be effected with great certainty and rapidity by admitting the patien into hospital for periods of two days on fire or six occasions and giving him intravenous injections of salrarsan; in addition he should receive systematic courses of mercurial injections or inunctions at the out patient department. Precisely how long a time will be necessary to abolish infectivity by such treatment has not been definitely ascertained. It is well known that the syphilitic patient with tertiary lesions is usually non-infective, and this is probably due in great part to the small number of suirochaetes which he harbours. Applying the same point of riew to cases treated energetically with salvar'san, it is most likely that they also are non-infective within a few weelis afterwards; but if complete sterilization lias not been effected a reculdescence may occur with, no doubt, rencwed infectivity. The prolonged subsequent treatment

The Public Hexlth Authority of Glasgow has already acted on this winciple by lo:oviding practition $3 r^{3}$ with the appliances for taling test on all specimens submitted.

A striking example of the syphilitic nature of a minor lesion with farty: wetl detined elinic al characters has been established $b y$ Findla and Witton (Lancet, March $29 \mathrm{th}, 1913$ ) in the case of chronic eczema
oris iu childrer by mcrcurial injections or inunctions aims at preventing this latter possibility.

The great difficulty centres in the question as to how treatment is to be onforced. Probably the first and nost important step in this direction is to disseminate to the widest possible extent an accurate knowledge of the nature of syphilis and its consequences, especially when not adequately treated. By this means chiefly will popular sympathy towards effective legislation be aroused, and then no doubt the disease will be made notifiable. Before this result is attained the educatire propagandia will have the effect of leading to early diagnosis and efficient treatment; sich has been the consequence of educative measures in the army. In the meantime no good object would be serred by the existence of special hospitals or even of special wards for such cases, since auy measures tending to stigmatize the individual will, by leading to concealment, interfere with thorongh treatment, and thus conduce to the further spread of the disease. Treatment by salvarsan is, of course, not so private as mercurial therapy, since the former requires a period of rest in bed, but the administration presents no great difficulties. and, with the aid of an assistant, conld be carried ont at the patient's home by any medical man who had received a short course of special training. Enlightenment as to the consequences of inadequate treatment mitst be counted upon to overcome prejudice regarding this degree of publicity. It is worth considering whether, from the point of riew of the health of the community, as well as of the indiridual, a most valuable object would not be served if public health anthorities wore prepared to supply salvarsan free of charge to practitioner's for the treatment of patients who could not themselves afford tc pay for the drug, just as has been done with diphtheria antitoxin.

If notification is capable of being applied at all in the meantime, some form might be devised for coercing those who, aware that they are suffering from the discase, do not submit to thorough treatment, by bringing them under the infectious diseases sections of the Public Health Acts; those individuals would then become liable to penalties for acting as sources of infection and for infecting articles such as drinking vessels, etc. 'This procedure, however, is likely to be practicable only in the case of patients in public practice.

It cannot be too greatly emphasized that thorough treatment constitutes, if not the only method, at least the most practicable means of exterminating the disease. The wide application of efficient diagnostic methods, including some test such as the Wassermann reaction, will prove invaluable as an indication where treatment is necessary. The information so acquired will be best utilized if every hospital and institution applies itself to treat thoroughly and unostentationsiy the cases which come within its reach. Thus valuable work in the direction of prevention as well as of cure can be effected by the special infirmaries for maternity, gynaccological and eye cases, etc., in addition to the general hospitals. In this way syphilitic women may be detected and abortions and congenital syphilis be obriated, or, again, the presence of latent congenital syphilis being detected, treatment may be applied to prevent the occurrence later on of such disabling and intractable conditions as interstitial keratitis.

\section{RWFEnENCE}

1 Gilmour, Journ of Ment. Science, vol. 1vii, 1911, p. 361. ${ }^{2}$ Browning and Mackenzie, Journ. of Ment. Science, vol. Iv, 1903, p. 437. 3 Fraser and Watson, Journ. of Ment. Science, October, 1913. 5 Dean, Pror. Roy. Soc. Med., 1910, vol. ili (Neur. Sect.), p. 1t. Serr Love, Glasy. ned. Journ., February- Mareh, 1919.

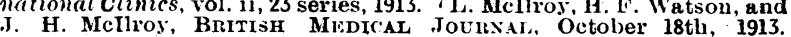
Wiratson, Bnitish MISDICAL JoUanal, April 26th, 1913. 9 McIntosh and Fildes. Syphilis from the Afodern Standpoint. Jondon, 1911. 11) Hutchinson, Proc, Rioy. Soc. Metl., 1912, vol. vi, p. 92. 11 Lane, ibid., 1. 87. 12 Browning and Mackenzie, Recent Ailvances in the Diagnosis
and Treatment of Sypltitis, London, 1911.

THE fifty-seventh course of lectures and demonstrations for sanitary officers arranged by the Royal Sanitary Institute will begsin on Monday, February 2nd. 'Ibo coinse for school teachers and others entering for the examinations in school hygiene will begin on February 16th. Further particulars can be obtained on application to the Secretary at the -Institute, 90, Buckingham Palace Road, S.W. 